\title{
The impact of plant growth promoting bacteria (PGPB) on the development of phytopathogenic fungi
}

\author{
ANNA GROBELAK*, ANNA NAPORA \& MAŁGORZATA KACPRZAK \\ Institute of Environmental Engineering, Częstochowa University of Technology, Brzeźnicka 60a, 42-200 \\ Czestochowa, Poland \\ E-mail: agrobelak@is.pcz.czest.pl
}

\begin{abstract}
The main purpose of this study was to evaluate impact of plant growth promoting bacteria (PGPB) on the development of phytopathogenic fungi and correlate it with a potential effects on the growth of plants under unfavorable conditions, in order to improve the efficiency of a phytoremediation process. The conducted research focused on the antifungal properties of PGPB. In this study, 51 isolates of bacteria were obtained after diversified disinfection time from plants growing on soil after sewage sludge amendment. The results revealed that some isolated bacteria, mainly endophytic ones, inhibited the development of Fusarium oxysporum, F. culmorum and Alternaria alternata.
\end{abstract}

KEY WORDS: plant growth promoting bacteria (PGPB), soil, pathogenic fungi

\section{Introduction}

Free-living soil bacteria are actually divided into three functional groups: plant growth promoting bacteria (PGPB), biocontrol PGPB and plant stress homeoregulating bacteria (PSHB). PGPB can promote plant growth and development by indirect or direct means (Cassán et al. 2009), that can facilitate plant growth of plants under optimal, biotic or abiotic stress conditions. They can also produce phytohormones and synthesize some less well characterized low molecular mass compounds or enzymes (Glick et al. 2007). Indirect plant growth promotion induced by biocontrol PGPB includes a variety of mechanisms by which the bacteria prevent phytopathogen deleterious effects. The beneficial effect of the bacteria varies significantly depending on individual bacterial strains, plant genotype, and growth conditions. Production of antibiotics by endophytes from plants, in particular the role of numerous species of Pseudomonas, whose antibiotic substances effectively limit the growth of plant pathogens is of particular importance (Klama 2004). The main purpose of the study was to evaluate impact of plant growth 
promoting bacteria (PGPB) on the development of phytopathogenic fungi and correlate it with the potential effect on the growth of plants under unfavorable conditions, in order to improve the efficiency of

\section{Material and methods}

Root samples were collected from plants of Festuca rubra L., Morus alba L. and Arabidopsis thaliana (L.) Heynh growing on fields contaminated with heavy metals and fertilized with municipal sewage sludge (one year after application) near zinc smelter in Miasteczko Śląskie (S Poland). The roots were washed, cut and treated with $70 \%$ ethanol. In this study different time of disinfection was used to isolate rhizobacteria (disinfection time 0 , only sterile distilled water was used) and endophytic bacteria (2.5 and $10 \mathrm{~min}$ disinfection followed by rinsing to eliminate ethanol). The disinfected roots were tested for surface sterility via incubation on solid nutrient agar medium for 3 days at $28^{\circ} \mathrm{C}$. The roots were homogenized, serially diluted and placed in differentiating media: Congo-Red agar (CRA) or nitrogen-free base (NFb) media to isolate free-living diazotrophic bacteria (Döbereiner 1995), in Luria agar (LA) to isolate nutritionally demanding bacteria, and Yeast-Extract-Manitol agar (YEMA) to isolate Rhizobiaceae bacteria. Next, plates were incubated at $30^{\circ} \mathrm{C}$ for 2 (CRA, NFb and LA) or 7 days (YEMA) to isolate bacteria. A total

\section{Results}

The potential biocontrol PGPB activity was evaluated based on antifungal activity in vitro, and results are phytoremediation process. The experiment was carried out to isolate strains of bacteria with the antifungal activity from plants grown on soil contaminated and fertilized with sewage sludge.

number of isolates of $F$. rubra was 9 , of M. alba was 16 and of $A$. thaliana was 26. Isolated bacteria were tested for gram coloration and screened for possible antifungal activity. The following fungi strains were used: FO - Fusarium oxysporum Schltdl., FC - F. culmorum (W.G. Sm.) Sacc., AA1 - A. alternata (Fr.) Keissler. 1, AA2 - A. alternata 2. Strains of $A$. alternata came from the collection of the Department of Forest Pathology University of Life Sciences in Poznan and were identified by microscopic analysis of the mycelium and conidia using available mycological keys. All isolated strains were assayed for antifungal activities using Potato Glucose Agar (PGA) medium. The bacteria were inoculated on PGA medium $(1 \mu \mathrm{L})$, then at the center of a plate a $3 \mathrm{~cm}$-diameter mycelium with pathogenic fungi was inoculated. Antifungal activity was examined for 10 days of incubation at $25^{\circ} \mathrm{C}$. Fungal mycelium without bacteria inoculation was used as a control. Mycelium growth inhibition was calculated as: (a-b/a) $\mathrm{x}$ 100\% (a: mycelium diameter in control, b: mycelium diameter in plates inoculated with bacteria).

summarized in Figures 1 to 3 for particular investigated plant species. 


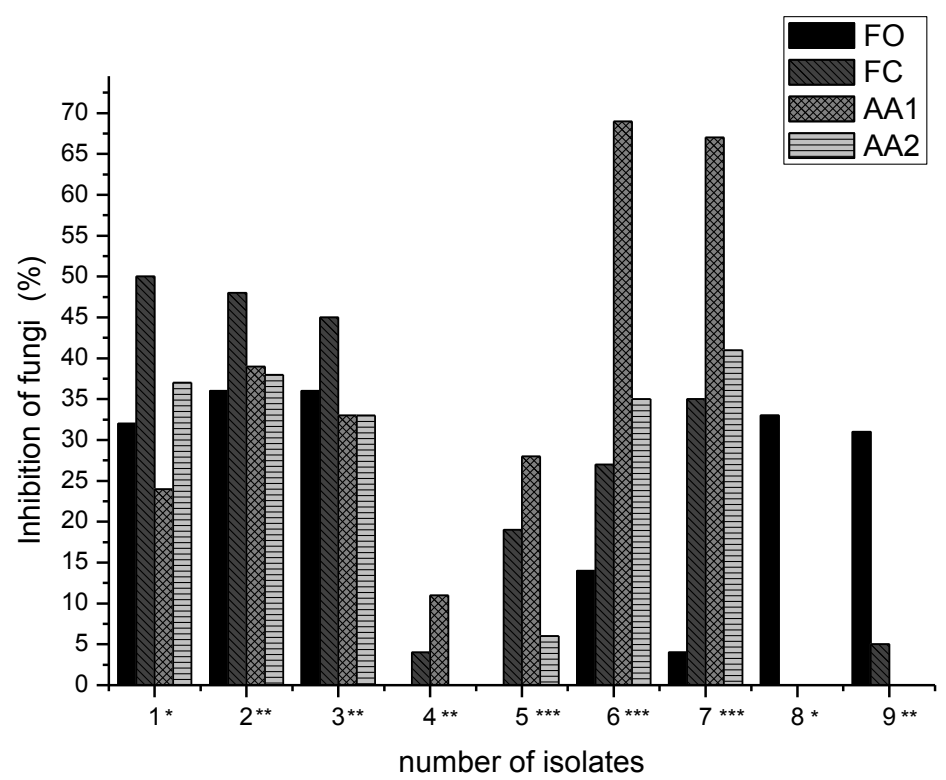

Figure 1. Antifungal activity of bacteria isolated from Festuca rubra (disinfection time: * -0 min; ** - 2.5 $\min ; * * *-10 \mathrm{~min})$.

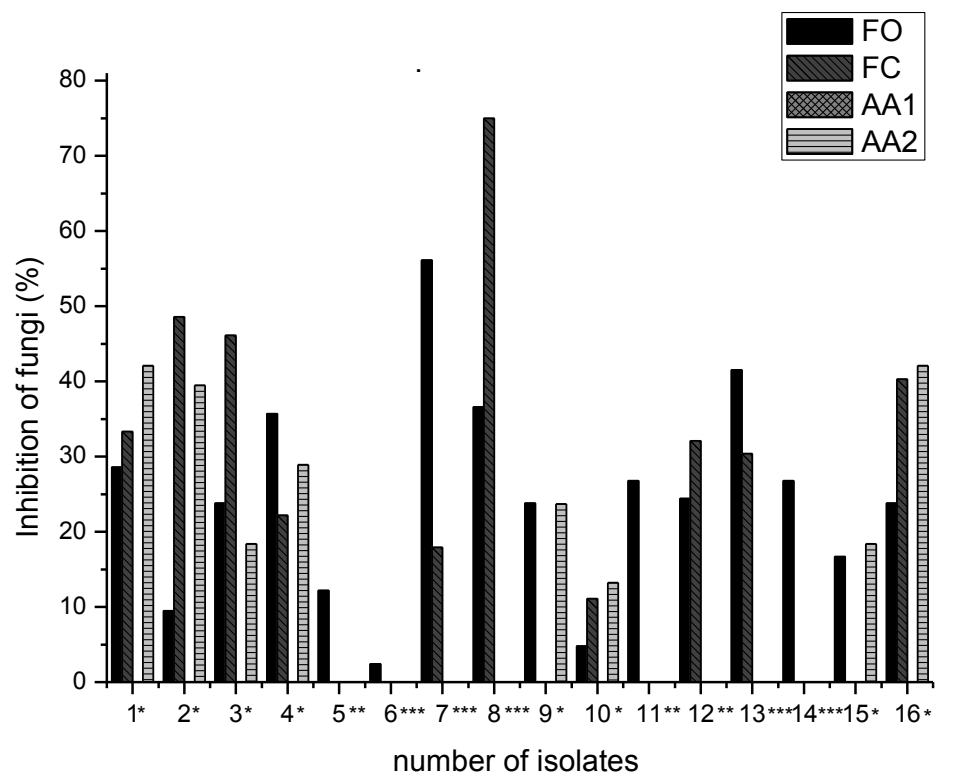

Figure 2. Antifungal activity of bacteria isolated from Morus alba (disinfection time: * - 0 min; ** - $2.5 \mathrm{~min}$; $* * *-10 \mathrm{~min})$. 


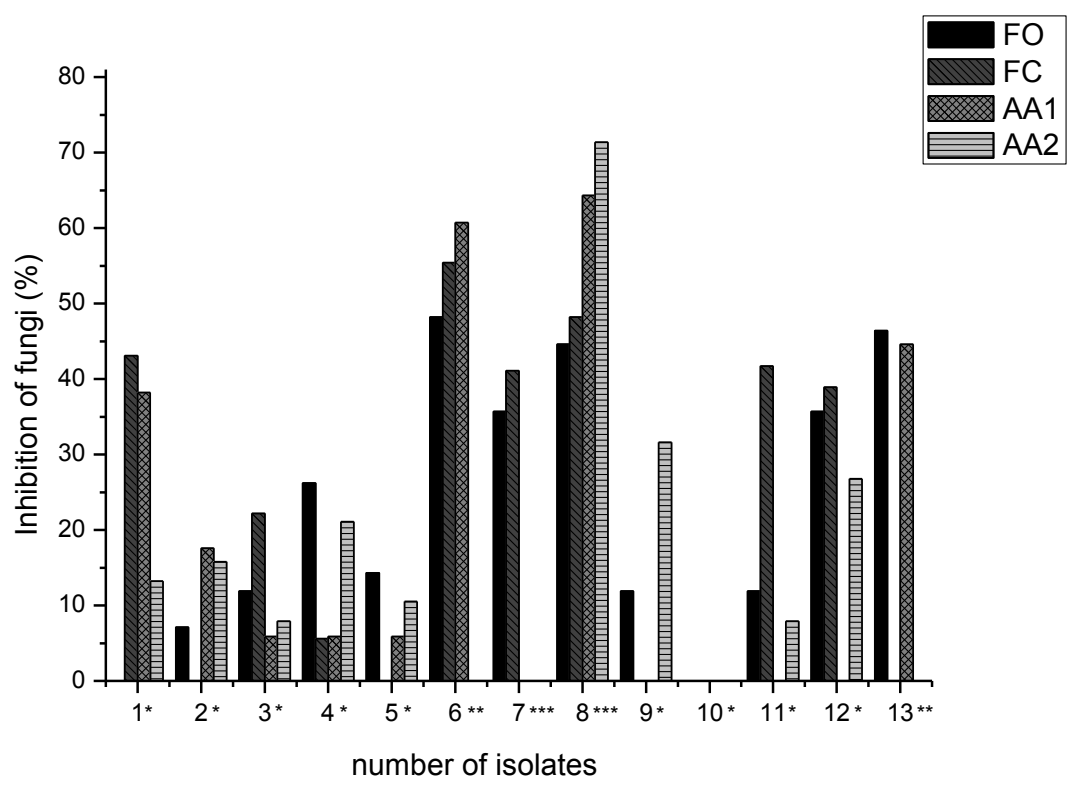

Figure 3A. Antifungal activity of bacteria strains (1-13) isolated from Arabidopsis thaliana (disinfection time: * $-0 \mathrm{~min} ; * *-2.5 \mathrm{~min} ; * * *-10 \mathrm{~min})$.

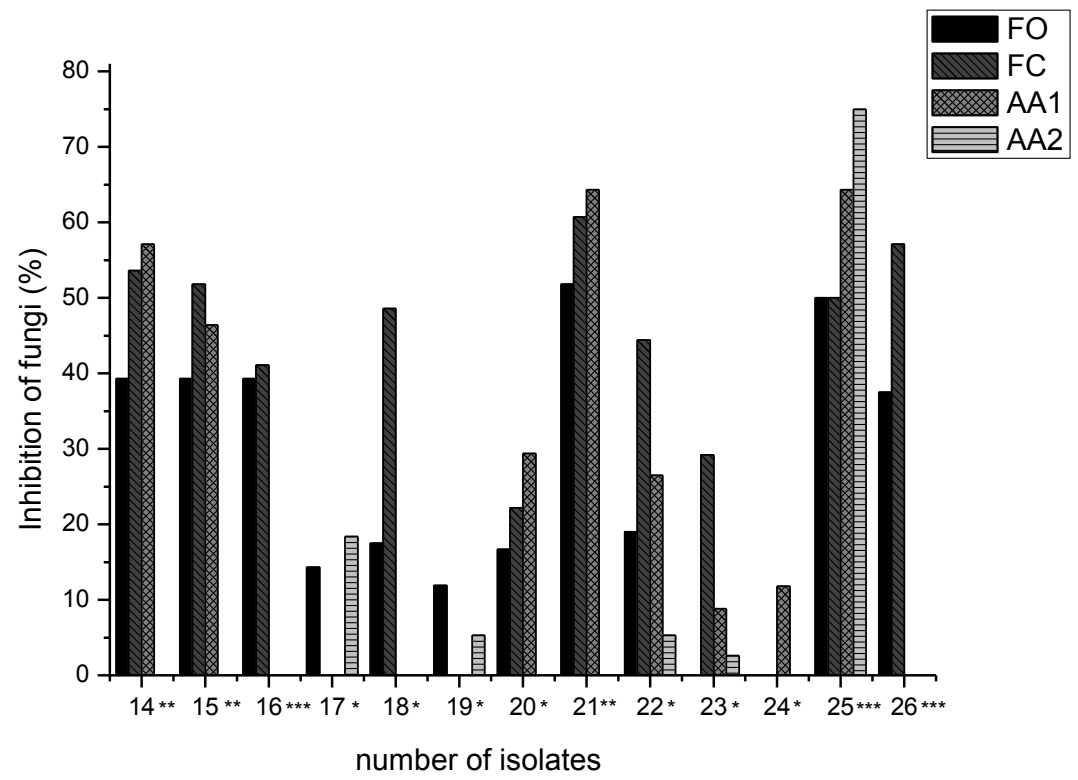

Figure 3B. Antifungal activity of bacteria strains (14-26) isolated from Arabidopsis thaliana (disinfection time: * - $0 \mathrm{~min} ; * *-2.5 \mathrm{~min} ; * * *-10 \mathrm{~min})$. 


\section{Discussion}

Knowledge concerning different interactions and antagonistic effects between microorganisms can be used to control plant pathogens causing root diseases or penetrating into plants through some roots. Bacteria inhibit fungal growth releasing antifungal substances and/or cell wall degrading enzymes released by the bacteria into the culture medium (Ligon et al. 2000). In this study most of the bacteria isolated from the investigated plants exhibited antifungal activity. From nine strains isolated from $F$. rubra (Fig. 1), five had the ability to simultaneously inhibit the growth of $F$. oxysporum, $F$. culmorum, $A$. alternata $1, A$. alternata 2 . Two isolates from $F$. rubra: 2 (YEMA, 2.5 min.), 3 (YEMA, 2.5 min.), potential endophytes, inhibited the growth of pathogenic fungi by over $30 \%$. The results of the conducted research are similar to Cho et al. (2007) and confirm that mainly endophytic bacteria have antifungal properties. These strains were isolated on a YEMA medium, specific for Rhizobiaceae. Moreover two of the isolated strains: $6(\mathrm{NFb}, 10 \mathrm{~min}$.) and 7 (NFb, 10 min.) were characterized by a very high degree of growth inhibition of A. alternata 1 , more than $65 \%$.

Among 16 strains isolated from $M$. alba (Fig. 2), the highest but overall modest inhibition of the pathogenic fungi growth ( $F$. oxysporum, $F$. culmorum and A. alternata 2 ) was found for isolates: 1 (NFb, 0 min.) and 16 (LA 0 min.) expressing more than $20 \%$ inhibition. Strain 8 (NFb, $10 \mathrm{~min}$.) isolated on a non-nitrogen medium after $10 \mathrm{~min}$. disinfection time (potential endophyte), had the highest capacity to inhibit the growth of $F$. culmorum by $75 \%$.

Moreover, the highest number of isolates (26) were obtained from the roots of A. thaliana (Fig. 3A, 3B). The widest spectrum of antifungal activity above 45 $\%$ was observed for two strains isolated on minimal media: strain 8 - potential endophyte (isolated on $\mathrm{NFb}, 10 \mathrm{~min}$ ) () and 25 (CRA, $10 \mathrm{~min}$.), also apparently an endophyte. Strain 8 had the highest antifungal activity $64 \%$ for $A$. alternata 1 and $71 \%$ for $A$. alternata 2 . The following strains: 21 (LA, $2.5 \mathrm{~min}$.) for $F$. oxysporum, $F$. culmorum and $A$. alternata 1 - more than $50 \%$ and 25 (CRA, $10 \mathrm{~min}$.) for $F$. oxysporum, $F$. culmorum and A. alternata 2 exhibited high antifungal properties. The other strains inhibited the growth of pathogenic fungi to a small extent.

In the conducted experiment it was shown that the strains isolated from the roots disinfected for $2.5 \mathrm{~min}$ and $10 \mathrm{~min}$ had the highest antifungal activity. As shown in other research, some of isolated bacterial strains can increase plant growth due to the inhibition of plant pathogenic fungi (Petatán-Sagahón et al. 2011, Weller 2007). Despite this, complementary experiments should be carried out with other fungal genera, like Pythium, Phytophthora, or Sclerotinia, to confirm the biocontrol capacity of each strain.

\section{Acknowledgements}

This work was supported by NCN-UMO-2011/03/N/NZ9/02034 grant. The authors are very grateful to prof. Hanna Kwaśna from Poznań Univerity of Agriculture for kindly supplying us with fungi strains. 


\section{References}

Cassán, F., Maiale, S., Masciarelli, O., Vidal, A., Luna, V. \& Ruiz, O. 2009. Cadaverine production by Azospirillum brasilense and its possible role in plant growth promotion and osmotic stress mitigation. European Journal of Soil Biology, 45:12-19.

Cho, K.M., Hong, S.Y., Lee, S.M., Kim, Y.H., Kahng, G.G., Lim, Y.P., Kim, H. \& Yun, H.D. 2007. Endophytic bacterial communities in ginseng and their antifungal activity against pathogens. Microbial Ecology, 54(2):341-351.

Döbereiner, J. 1995. Isolation and identification of aerobic nitrogen-fixing bacteria from soil and plants. In: Alef K. \& Nannipieri P. (eds), Methods in Applied Soil Microbiology and Biochemistry. Academic Press, London, San Diego, New York, Boston, Sydney, Tokyo, Toronto, pp. 134-141.

Glick, B.R., Todorovic, B., Czarny, J., Cheng, Z. \& Duan, J. 2007. Promotion of plant growth by bacterial ACC deaminase. Critical Reviews in Plant Sciences, 26: 227-242.

Klama, J. 2004. Współżycie endofitów bakteryjnych z roślinami. Acta Scientiarum Polonorum. Agricultura, 31: 19-28.

Ligon, J.M., Hill, D.S., Hammer, P. E., Torkewitz, N.R., Hofmann, D., Kempf, H.J. \& Pe'e van, K.H. 2000. Natural products with antifungal activity from Pseudomonas biocontrol bacteria. Management Science, 56: 688-695.

Petatán-Sagahón, I., Anducho-Reyes, M.A., SilvaRojas, H.V., Arana-Cuenca, A., Tellez-Jurado, A., Cárdenas-Álvarez, I.O. \& Mercado-Flores, Y. 2011. Phytopathogenic fungi Stenocarpella maydis and Stenocarpella macrospora. International Journal of Molecular Sciences, 12: 5522-5537.

Weller, D. M. 2007. Pseudomonas biocontrol agents of soilborne pathogens: Looking back over 30 years. Phytopathology, 97: 250-256.

\section{Streszczenie}

Bakterie promujące wzrost roślin (PGPB) to wolno żyjące organizmy glebowe, które mogą bezpośrednio lub pośrednio ułatwiać wzrost roślin w biotycznych lub abiotycznych warunkach stresowych. Mogą także produkować fitohormony i syntezować związki lub enzymy, które mogą modulować wzrost i rozwój (Glick et al. 2007). Pośrednie promowanie wzrostu roślin obejmuje wiele mechanizmów, dzięki którym bakterie mogą ograniczać rozwój patogenów roślinnych. Korzystny wpływ na wzrost roślin zmienia się znacznie w zależności od indywidualnych szczepów bakteryjnych oraz warunków wzrostu. Ważnym zjawiskiem jest produkcja antybiotyków przez bakteryjne endofity roślinne, w szczególności obserwowane u licznych gatunków Pseudomonas. Substancje te skutecznie ograniczają wzrost patogenów roślinnych (Klama, 2004).

Celem badań było wyizolowanie bakterii strefy korzeniowej i ocena inhibicji wzrostu grzybów będących patogenami roślin wobec wyizolowanych szczepów bakteryjnych.

W przeprowadzonych badaniach wykorzystano rośliny (Festuca rubra, Morus alba, Arabidopsis thaliana) rosnące w pobliżu huty cynku w Miasteczku Śląskim na glebie zanieczyszczonej metalami ciężkimi i nawożonej komunalnymi osadami ściekowymi. Bakterie izolowano z korzeni roślin stosując trzy długości czasu dezynfekcji $(0,2.5,10$ min). Po uzyskaniu czystych kultur bakteryjnych prowadzono testy zahamowania wzrostu w warunkach in vitro wobec czterech szczepów grzybów: FO - Fusarium oxysporum, $\mathrm{FC}-F$. culmorum, AA1 - Alternaria alternata 1, AA2 - A . alternata 2.

Wyniki eksperymentu wskazują, że bakterie izolowane po czasie 2.5 i 10 minut sterylizacji, czyli głównie bakterie endofityczne, hamowały rozwój badanych grzybów - potencjalnych patogenów roślin. Badania wykazały także, że z rzodkiewnika pospolitego (Arabidopsis thaliana), znanego halofita, pozyskano najwyższą liczbę mikroorganizmów, które także wykazywały najlepsze właściwości inhibitujące wzrost grzybni wszystkich badanych patogenów. 